ROZ D Z I A E 7 .

\title{
RACHUNKOWOŚĆ ROLNICZA W ŚWIETLE KRAJOWYCH I MIĘDZYNARODOWYCH REGULACJI RACHUNKOWOŚCI
}

\author{
Anna Dyhdalewicz ${ }^{1}$
}

\section{Wstęp}

Rachunkowość od wieków stanowi system pomiaru, ewidencji procesów gospodarczych, prezentacji informacji o majątku od strony rzeczowej i finansowej oraz uzyskiwanych przychodach i ponoszonych kosztach, a w konsekwencji o osiąganych wynikach finansowych ${ }^{2}$. Jak stwierdza Jacek Jaworski „zgodnie z zasadą jasnego i rzetelnego obrazu, rachunkowość w gospodarstwie rolnym, jak w każdej jednostce, powinna odzwierciedlać wszystkie procesy i rejestrować każdą operację"3. Jednak z uwagi na specyficzne cechy produkcji rolnej kompleksowe ujęcie księgowe stwarza problemy. Cechami produkcji rolnej, które wpływają na odróżnienie tej działalności od działalności w innych działach, są, m.in. biologiczny charakter produkcji, różne cykle produkcyjne i stopień zaawansowania produkcji, uzależnienie od warunków przyrodniczych i agrotechnicznych,

${ }^{1}$ Dr Anna Dyhdalewicz, Politechnika Białostocka.

2 A. Dyhdalewicz, Podstawy rachunkowości jednostek gospodarczych, Oficyna Wydawnicza Politechniki Białostockiej, Białystok 2013, s. 7.

3 J. Jaworski, Założenia koncepcyjne rachunku kosztów i wyników gospodarstwa rolnego, „Zeszyty Teoretyczne Rachunkowości” 2007, t. 41(97), s. 115. 
zależność wielkości i jakości produkcji od czynników niekontrolowanych, takich jak: warunki pogodowe, choroby roślin i zwierząt czy też skomplikowany obrót wewnętrzny polegający na wykorzystaniu np. własnej produkcji roślinnej do produkcji zwierzęcej.

W piśmiennictwie krajowym problematyka rachunkowości w rolnictwie podejmowana jest przez wielu autorów. Według Tomasza Kondraszuka „Rachunkowość rolnicza jest specyficznym systemem ewidencji gospodarczej dostosowanej do warunków produkcji rolniczej i sytuacji gospodarstw wiejskich"4. Podejście do tej problematyki podkreśla jej aspekt aplikacyjny. Główne obszary badawcze opisywane w literaturze przedmiotu to:

1. Rozważania dotyczące historii i istoty rachunkowości rolniczej w Polsce i na świecie oraz perspektywy jej rozwoju (Kondraszuk 2003, Nieszporek-Wolak 2004; Bernacki 2007, Turzyński 2010, Turzyński 2016) 5 .

2. Rachunek kosztów w przedsiębiorstwach rolniczych, ustalanie dochodów rolniczych oraz problemy opodatkowania rolnictwa (Jaworski 2007, Kondraszuk 2011; Pieczonka 2011, Hajduga 2013; Hajduga 2015, Kryszak, 2017, Jaworski, Sokołowska, Kondraszuk 2017) ${ }^{6}$.

${ }^{4}$ T. Kondraszuk, Ewidencja kosztów w przedsiębiorstwach rolniczych, „Zeszyty Naukowe Uniwersytetu Szczecińskiego” 2011, nr 625, „Finanse, Rynki, Ubezpieczenia" 2011, nr 32, s. 50.

${ }^{5}$ T. Kondraszuk, Nowe wyzwania dla rachunkowości rolniczej, [w:] Historia, wspótczesność i perspektywy rachunkowości w Polsce, S. Sojak (red.), Uniwersytet M. Kopernika Wydział Nauk Ekonomicznych i Zarządzania Katedra Rachunkowości, Toruń 2003, s. 347-357; J. Nieszporek-Wolak, Zarys historii rachunkowości rolniczej w Polsce, [w:] Polska szkoła rachunkowości, M. Gmytrasiewicz, A. Karmańska (red.), SGH w Warszawie, Warszawa 2004, s. 311-317; A.M. Bernacki, Rachunkowość rolnicza $w$ Polsce. Historia i rzeczywistość, „Roczniki Naukowe Stowarzyszenia Ekonomistów Rolnictwa i Agrobiznesu" 2007, t. 9, z. 1, s. 38-44; M. Turzyński, Rachunkowość bałamutna a rachunkowość porządna: teoria rachunkowości rolniczej Juliusza Au, „Zeszyty Teoretyczne Rachunkowości” 2010, t. 55(111), s. 197-210; M. Turzyński, Rozwój rachunkowości rolnej na ziemiach polskich od XVI do XIX wieku w świetle badań instruktarzy ekonomicznych, „Roczniki Naukowe SERiA” 2016, t. XVIII, z. 1, s. 271-275.

6 J. Jaworski, dz. cyt., s. 115-130; T. Kondraszuk, Ewidencja kosztów..., s. 449562; J. Pieczonka, Forma ewidencji księgowej $w$ kontekście potrzeb informacyjnych 
3. Zastosowanie koncepcji zarządzania do monitorowania efektów działalności rolniczej (Kondraszuk 2008, Kondraszuk, Jaworski 2013) ${ }^{7}$.

4. Rozważania na temat parametrów i zasad wyceny składników majątkowych w gospodarstwach rolnych (Kucharczyk 2002, Nadolna, Rydzewska-Włodarczyk 2009, Prymon 2012; Grabiński 2013, Nemś, Sadowska, Szczypa 2018) ${ }^{8}$.

gospodarstw rolnych, „Zeszyty Naukowe SGGW w Warszawie, Ekonomika i Organizacja Gospodarki Żywnościowej" 2011, nr 92, s. 51-62; E. Hajduga, The system of cost account in agricultural accounting, „Prace Naukowe Uniwersytetu Ekonomicznego we Wrocławiu 2013, nr 302, Finance and Accountancy for Sustainable Development: Sustainable Finance, 2013, s. 47-56; E. Hajduga, Klasyfikacja kosztów na potrzeby rachunkowości rolnej, „Prace Naukowe Wałbrzyskiej Wyższej Szkoły Zarządzania i Przedsiębiorczości” 2015, t. 34(4), s. 95-107; Ł. Kryszak, Wybrane problemy rachunku dochodów rolniczych, „Roczniki Naukowe SERiA” 2017, t. XIX, z. 3, s. 168-173.

${ }^{7}$ T. Kondraszuk, Rachunkowość zarzq̨dcza $w$ rolnictwie $w$ warunkach globalizacji, „Prace Naukowe Uniwersytetu Ekonomicznego we Wrocławiu” 2008, nr 14, Rachunkowość a Controlling, s. 174-182; T. Kondraszuk, J. Jaworski, Ramy koncepcyjne zastosowania strategicznej karty wyników w gospodarstwie wiejskim, „Zeszyty Teoretyczne Rachunkowości” 2013, t. 74(130), s. 45-64; J. Jaworski, K. Sokołowska, T. Kondraszuk, Wykorzystanie narzędzi zarzaddzania strategicznego $w$ gospodarstwach rolniczych $w$ Polsce. Wyniki badań, „Roczniki Naukowe Stowarzyszenia Ekonomistów Rolnictwa i Agrobiznesu" 2016, nr 18, z. 1, s. 105-110.

${ }^{8}$ M. Kucharczyk, Uwarunkowania wyceny aktywów według Międzynarodowego Standardu Rachunkowości 41 - Rolnictwo, [w:] Rachunkowość wobec procesów globalizacji, J. Gierusz, M. Jerzemowska, T. Martyniuk (red.), Uniwersytet Gdański, Gdańsk 2002, s. 287-291; B. Nadolna, M. Rydzewska-Włodarczyk, Księgowe ujęcie aktywów biologicznych, „Folia Pomeranae Universitatis Technologiae Stetinensis” 2009, „Oeconomica”, nr 275(57), s. 77-84; K. Prymon, Możliwości wprowadzenia modelu wartości godziwej w rolnictwie, „Prace Naukowe Uniwersytetu Ekonomicznego we Wrocławiu" 2012, nr 251, Rachunkowość a Controlling, s. 407-417; K. Grabiński, Zmiana wyceny składników bilansowych na przykładzie MSR 41 „Rolnictwo”, „Zeszyty Naukowe Uniwersytetu Ekonomicznego w Krakowie” 2013, nr 901, s. 57-70; M. Nemś, M. Sadowska, P. Szczypa, Parametry $i$ zasady wyceny nieruchomości leśnych $w$ rachunkowości: wycena drzewostanów, „Zeszyty Teoretyczne Rachunkowości” 2018, t. 96(152), s. 109-121. 
5. Problematyka prezentacji informacji finansowych i niefinansowych w sprawozdaniu finansowym (Łagodzki 2008, Węgrzyńska, Pereira López, Carballido 2018, Śmiglak-Krajewska, Węgrzyńska 2018) ${ }^{9}$.

6. Rozwiązania prawa bilansowego w zakresie działalności rolniczej (Rydzewska-Włodarczyk 2008, Czerwińska-Kayzer, Bieniasz 2011, Gałecka 2015, Kondraszuk 2018) ${ }^{10}$.

W opracowaniu, z uwagi na ograniczenia objętości tekstu, przedmiotem rozdziału są wybrane problemy rachunkowości rolnej w świetle aktualnych krajowych i międzynarodowych przepisów prawa bilansowego. Natomiast jego celem jest dokonanie przeglądu wybranych rozstrzygnięć w ramach Międzynarodowego Standardu Rachunkowości 41 Rolnictwo (MSR 41) oraz Krajowego Standardu Rachunkowości nr 12 Działalność rolnicza (KSR 12), które określają specyfikę rachunkowości w rolnictwie oraz wyznaczają kierunek jej rozwoju. Z tego też względu rozdział stano-

${ }^{9} \mathrm{P}$. Łagodzki, Obowiązki sprawozdawcze $w$ zakresie sporządzania rachunku przepływów pieniężnych według MSR 41 „Rolnictwo” i ustawy o rachunkowości, „Zeszyty Naukowe Uniwersytetu Szczecińskiego” 2008, nr 493, „Finanse, Rynki Finansowe, Ubezpieczenia” 2008, nr 9, s. 243-250; M. Węgrzyńska, X. Pereira López, M. Veiga Carballido, Zakres prezentacji informacji niefinansowych $w$ rocznym sprawozdaniu gospodarstwa rolnego na przykładzie produkcji roślinnej, „Zeszyty Teoretyczne Rachunkowości” 2018, t. 100(156), s. 191-210; M. Śmiglak-Krajewska, M. Węgrzyńska, Zakres zintegrowanego sprawozdania gospodarstw rolnych na przykładzie produkcji bobiku, „Studia i Prace Kolegium Zarządzania i Finansów. Zeszyt Naukowy” 2018, nr 160, s. 137-149.

${ }^{10}$ M. Rydzewska-Włodarczyk, Rachunkowość rolna jako system informacyjny gospodarstw rolnych, [w:] Informacyjna funkcja rachunkowości w gospodarce współczesnej, A. Dyhdalewicz, G. Klamecka-Roszkowska, J. Sikorski (red.), Wydawnictwo Uniwersytetu w Białymstoku, Białystok 2008, s. 343-349; D. Czerwińska-Kayzer, A. Bieniasz, Klasyfikacja aktywów pochodzenia rolniczego według MSR 41, “Journal of Agribusiness and Rural Development" 2011, nr 4(22), s. 41-49; A. Gałecka, Zakres i znaczenie rachunkowości rolniczej w Polsce, „Studia i Materiały Miscellanea Oeconomicae" 2015, nr 3, s. 97-108; T. Kondraszuk, Projekt Krajowego Standardu Rachunkowości „Działalność rolnicza” - ocena proponowanych regulacji, „Zeszyty Teoretyczne Rachunkowości” 2018, t. 100(156), s. 211-224. 
wi pewnego rodzaju analizę porównawczą zasad wynikających z zapisów ustawy o rachunkowości (UoR) oraz MSR 41 i KSR 12.

Dla osiągnięcia celu przeprowadzono krytyczną analizę literatury z zakresu rachunkowości rolniczej oraz krajowych i międzynarodowych regulacji w tym obszarze. Konkluzje zawarte w publikacji zostały sformułowane na podstawie wnioskowania logicznego, z wykorzystaniem metody dedukcji.

\subsection{Geneza kształtowania się rachunkowości rolniczej}

Problemy ze zrozumieniem funkcjonowania rachunkowości w rolnictwie mają długą historię, od zarania dziejów stosowano i doskonalono różne formy ewidencji działalności gospodarczej w rolnictwie ${ }^{11}$. Celem ewidencji była kontrola posiadanego majątku, ustanawianie świadczeń na rzecz książąt lub duchowieństwa, będących właścicielami majątków ziemskich czy też podejmowanie wewnętrznych decyzji. Z czasem majątki ziemskie nabrały charakteru przedsiębiorstw. Już pod koniec XVIII wieku, kiedy działalność rolnicza z form feudalnych zaczęła przybierać postać przedsiębiorstw rolnych, zaczęto negować tradycyjną księgowość rolniczą. Była ona określana tzw. księgowością kameralną (księgowością pojedynczą rolniczą), skoncentrowaną na stanie posiadania. Według tego systemu obliczano roczny wynik działalności gospodarstwa, podobnie jak w drobnych gospodarstwach, jako różnicę między pieniężnymi przychodami i rozchodami skorygowaną o różnicę inwentur oraz świadczeń między gospodarstwem a jego właścicielem. Zakres ewidencji wynikał z potrzeb właścicieli. Podstawową funkcją rachunkowości było zapewnienie kontroli nad wykorzystaniem posiadanych zasobów w produkcji rolnej, zabezpieczenie majątku przed nadużyciami i kradzieżami oraz nastawienie na

${ }^{11}$ Szerzej: M. Węgrzyńska, X. Pereira López, M. Veiga Carballido, dz. cyt., s. 191210. 
ograniczanie kosztów i zwiększanie korzyści dla właścicieli ${ }^{12}$. W pierwszej połowie XIX wieku ewidencja została zdominowana przez tzw. księgowość kupiecką (wykorzystującą podwójny zapis, zwaną też analityczną), szczególnie przydatną w gospodarstwach wieloobszarowych, umożliwiającą obliczanie opłacalności oddzielnie dla poszczególnych działów, gałęzi wydzielonych w gospodarstwie. Jednak w praktyce była ona uznawana za pracochłonną i skomplikowaną, przez co pojawiły się i rozpowszechniły rozwiązania proponujące uproszczenie systemu ewidencji księgowej na rzecz systemu pojedynczej księgowości. Głównym problemem było małe zainteresowanie ze strony rolników prowadzeniem zapisów księgowych ${ }^{13}$. Od połowy lat 50. ubiegłego wieku zarzucono w rolnictwie dokonywanie rachunku efektywności w systemie rachunkowości podwójnego zapisu i wprowadzono szereg uproszczeń. Rachunkowość różniła się w zależności od form społeczno-gospodarczych w rolnictwie, tj. gospodarstw państwowych, spółdzielni produkcyjnych i gospodarstw indywidualnych.

W krajach UE już w 1965 roku zatwierdzono przepis, na mocy którego zorganizowano system do gromadzenia informacji z zakresu rachunkowości gospodarstw rolnych (Farm Accountancy Data Network - FADN). Jego zadaniem jest zbieranie informacji rachunkowych potrzebnych do ustalenia dochodów gospodarstw rolnych objętych badaniem i do analizy ich działalności we wszystkich krajach w systemie tym uczestniczących. Dane te służą do kreowania wspólnej polityki rolnej UE. Grupy państw tworzące obecnie UE znacznie się różnią. W byłych państwach członkowskich struktura agrarna jest ustabilizowana, tworzą ją duże obszarowo gospodarstwa rodzinne o znacznym potencjale ekonomicznym. Nowe państwa członkowskie charakteryzuje bardzo zróżnicowana struktura agrarna o różnych formach prawnych i stosunkowo małych możliwościach konkurowania na wspólnym rynku ${ }^{14}$. Problemy związane z rolnictwem, poszukiwanie

2 M. Turzyński, Rozwój rachunkowości..., s. 271-275.

13 J. Nieszporek-Wolak, dz. cyt., s. 314.

${ }^{14}$ A. Sadowski, Konkurencyjność rolnictwa nowych i starych państw członkowskich UE, „Roczniki Naukowe SERiA” 2008, t. 10, z. 1, s. 355. 
rozwiązań w zakresie rachunkowości rolniczej są wciąż aktualne zarówno w skali regionalnej, jak i międzynarodowej.

W Polsce w 1995 roku powołano grupę roboczą dla opracowania i wdrożenia Zunifikowanego Systemu Rachunkowości dla Gospodarstw Rolnych (ZSRGR), którego zadaniem było ujednolicenie zasad ewidencji, przetwarzania i sprawozdawczości rachunkowości rolniczej. Od 1996 roku wymóg prowadzenia rachunkowości rolniczej był wprowadzony w odniesieniu do rolników zaciągających kredyty subwencjonowane przez Agencję Modernizacji i Restrukturyzacji Rolnictwa ${ }^{15}$.

Od 2003 roku opracowany FADN na podstawie doświadczeń Zunifikowanego Systemu Rachunkowości Gospodarstw Rolnych, zapewniał zgodność krajowych rozwiązań z przepisami UE dotyczącymi zbierania danych rachunkowych z gospodarstw rolnych ${ }^{16}$. Po trzech latach jego prowadzenia ostatecznie wdrożono Polski FADN, który obejmował dane dotyczące księgowości, rachunku kosztów i sprawozdawczości finansowej. System FADN kładzie nacisk na efektywność gospodarowania. Informacje zbierane za jego pośrednictwem wykorzystywane są do mierzenia dochodów gospodarstw rolniczych, prezentacji sytuacji finansowej w bilansie, kasowych wyników finansowych oraz wykorzystywane są do porównania gospodarstw polskich z gospodarstwami z innych krajów europejskich. Nieliczni jednak rolnicy prowadzą zapisy o charakterze księgowym. Należą do nich rolnicy z około 12 tys. gospodarstw rolnych. Ewidencja dla celów FADN odbiega od tej wymaganej ustawą o rachunkowości, może jednak wpływać na upowszechnienie prowadzenia ewidencji księgowej w gospodarstwach rolniczych ${ }^{17}$.

15 T. Kondraszuk, Nowe wyzwania dla rachunkowości rolniczej, [w:] Historia, wspótczesność i perspektywy rachunkowości $w$ Polsce, S. Sojak (red.), Uniwersytet M. Kopernika Wydział Nauk Ekonomicznych i Zarządzania Katedra Rachunkowości, Toruń 2003, s. 352.

${ }^{16}$ T. Kondraszuk, Nowe wyzwania..., dz. cyt., s. 353; tenże, Ewidencja kosztów..., s. 555; tenże, Projekt Krajowego..., s. 217.

17 Szerzej na temat problemów badawczych w zakresie dochodów rolniczych i ich determinant oraz kierunków rozwoju badań w tym zakresie oraz bazy danych 
Obecnie do prowadzenia rachunkowości zgodnie z UoR zobowiązane są gospodarstwa rolnicze posiadające osobowość prawną. W przypadku indywidualnych gospodarstw rolnych (osób fizycznych, spółek osób fizycznych) obowiązek prowadzenia ksiąg rachunkowych wynika z rozmiaru prowadzonej działalności ${ }^{18}$. Przedsiębiorstwa mają obowiązek gromadzenia i przetwarzania danych oraz sporządzania okresowego sprawozdania finansowego zgodnie z przepisami prawa bilansowego na potrzeby zewnętrznych użytkowników informacji, a także przydatnych w zarządzaniu gospodarstwem rolnym.

\subsection{Regulacje międzynarodowe i krajowe w zakresie rachunkowości rolniczej}

Rolnictwo w literaturze przedmiotu postrzegane jest (zwłaszcza przez ekonomistów rolnictwa), jako dział gospodarki chrakteryzujący się pewną specyfiką warunkującą jego funkcjonowanie. Cechy produkcji rolnej to: sezonowość, przestrzenność, podwyższone ryzyko i niepewność, warunkowane czynnikami biologicznymi i przyrodniczymi, łączne występowanie funkcji producenta i konsumenta charakterystyczne dla rodzinnej formy gospodarowania ${ }^{19}$. Rozwój sektora gospodarstw rolniczych zdeterminował powstanie przedsiębiorstw rolniczych w coraz to większym rozmiarze, często zorganizowanych w formie spółek kapitałowych, które zobowiązane są do prowadzenia ksiąg rachunkowych. Specyfika działalności gospodarstw rolnych znalazła swój wyraz w Międzynarodowym Standardzie Rachun-

FADN i Rachunków Ekonomicznych dla Rolnictwa - EUROSTAT: A. Gałecka, dz. cyt., s. 97-108; Ł. Kryszak, dz. cyt., s. 168-173.

${ }^{18}$ Obowiązek dotyczy gospodarstw, których przychody netto ze sprzedaży produktów, towarów i operacji finansowych za poprzedni rok obrotowy wyniosły co najmniej równowartość w walucie polskiej 2 mln euro.

${ }^{19}$ R.I. Dziemianowicz, Efektywność systemu opodatkowania rolnictwa, Wydawnictwo Uniwersytetu w Białymstoku, Białystok 2007, s. 125-126. 
kowości 41 Rolnictwo (MSR 41)20. W 1994 roku Komitet Międzynarodowych Standardów Rachunkowości (IASC) podjął decyzję o opracowaniu standardu dotyczącego rolnictwa. Potrzeba jego opracowania wynikała z następujących przesłanek ${ }^{21}$ :

1. Rolnictwo, jako jedna z ważniejszych gałęzi gospodarki krajowej, charakteryzuje się określoną specyfiką procesów produkcji, wskutek czego wymaga odmiennego ich ujęcia i wyceny niż w innych sektorach.

2. Konieczność ujednolicenia zasad odzwierciedlania zdarzeń związanych z przemianą biologiczną.

3. Brak całościowego ujmowania zagadnień dotyczących działalności rolniczej przez wcześniejsze regulacje rachunkowości.

4. Wyłączenia z zakresu MSR aktywów związanych z działalnością rolniczą oraz ich zmian.

Według IASC większość jednostek prowadzących działalność rolniczą to małe, niezależne gospodarstwa rodzinne, koncentrujące się na rozliczeniach podatkowych i działające w oparciu o zasadę kasową. Przedsiębiorstwa te nie podlegają obowiązkowi sporządzania sprawozdań finansowych o ogólnym przeznaczeniu. Jednak poszukują one zewnętrznych źródeł finansowania i dotacji od podmiotów, które wymagają ich sporządzania. Ponadto globalizacja prowadzi do zwiększania się skali, zakresu i komercjalizacji działalności rolniczej, co powoduje konieczność sporządzania sprawozdań finansowych opartych na solidnych i powszechnie uznawanych zasadach ${ }^{22}$.

${ }^{20}$ Międzynarodowy Standard Rachunkowości 41 Rolnictwo, [w:] Międzynarodowe Standardy Sprawozdawczości Finansowej według stanu na dzień 1 stycznia 2013 r., SKwP, IFRS, Warszawa 2014, s. 1247-1261.

${ }^{21}$ P. Łagodzki, Obowiązki sprawozdawcze w zakresie sporzadzania rachunku przepływów pieniężnych według MSR 41 „Rolnictwo” i ustawy o rachunkowości, „Zeszyty Naukowe Uniwersytetu Szczecińskiego” 2008, nr 493, „Finanse, Rynki Finansowe, Ubezpieczenia" 2008, nr 9, s. 243.

${ }^{22}$ Międzynarodowe Standardy sprawozdawczości Finansowej, Część B. Dokumenty towarzyszace, SKwP, IFRS, Warszawa, Londyn 2011, s. B1652-1653. 
Ostateczna wersja standardu została zatwierdzona w grudniu 2000 roku, po uwzględnieniu uwag do projektu różnych organizacji międzynarodowych, jednostek gospodarczych oraz wyników skierowanej do gospodarstw rolnych ankiety, dotyczącej oceny proponowanych rozwiązań, w szczególności wyceny w wartości godziwej. Od 1 stycznia 2003 roku europejskie przedsiębiorstwa rolne zaczęły wykorzystywać w swojej rachunkowości założenia przewidziane w tym standardzie. Zakres tematyczny MSR 41 określa sposób księgowania, prezentację w sprawozdaniach finansowych oraz ujawnianie informacji na temat prowadzonej działalności rolniczej. Standard zwraca szczególną uwagę na sposób identyfikacji, pomiaru oraz komunikowania informacji dotyczących aktywów biologicznych, produktów rolnych na moment ich pozyskania i w późniejszym czasie po momencie pozyskania oraz dotacji państwowych otrzymywanych na działalność rolniczą ${ }^{23}$. Jacek Jaworski podkreślił, że zamiast kompleksowych uregulowań dotyczących specyfiki działania gospodarstw rolnych, prezentuje głównie problematykę wyceny aktywów biologicznych ${ }^{24}$. Z kolei Tomasz Kondraszuk stwierdził, że standard ten „otworzył drogę do tworzenia jasnych i przejrzystych zasad ewidencji i analizy kosztów działalności przedsiębiorstw rolniczych w ramach ponadnarodowych systemów informacyjnych"25.

Obowiązująca w Polsce ustawa z dnia 29 września 1994 roku o rachunkowości ${ }^{26}$ nie zawiera osobnych regulacji odnoszących się do działalności rolniczej i aktywów biologicznych, kwestie z nimi związane podlegają przepisom ustawy na ogólnych zasadach. Należy podkreślić, że od wielu lat krajowe przepisy obowiązujące przy prowadzeniu rachunkowości

${ }^{23}$ Por. M. Kucharczyk, Uwarunkowania wyceny aktywów według Międzynarodowego Standardu Rachunkowości 41 - Rolnictwo, [w:] Rachunkowość wobec procesów globalizacji, J. Gierusz, M. Jerzemowska, T. Martyniuk (red.), Uniwersytet Gdański, Gdańsk 2002, s. 287.

24 J. Jaworski, Założenia koncepcyjne rachunku kosztów i wyników gospodarstwa rolnego, „Zeszyty Teoretyczne Rachunkowości” 2007, t. 41(97), s. 116.

25 T. Kondraszuk, Ewidencja kosztów..., s. 561.

${ }^{26}$ Ustawa z dnia 29 września 1994 r. o rachunkowości, Dz.U. z 2018 r., poz. 39, z późn. zm. 
podlegają stopniowej harmonizacji z prawem międzynarodowym oraz dostosowywaniu do wymogów wynikających z integracji z UE ${ }^{27}$. W treści art. 10 ust. 3 ustawy wskazano na hierarchię przepisów obowiązujących jednostki prowadzące rachunkowość i sporządzające sprawozdania finansowe w oparciu o UoR. Do rozwiązywania zagadnień nieuregulowanych lub w sytuacjach wątpliwych z powodu nieprecyzyjnych zapisów ustawy, mogą być brane pod uwagę standardy krajowe, a w razie ich braku standardy międzynarodowe. Przedsiębiorstwa rolnicze mogły przez wiele lat wykorzystywać rozwiązania zawarte w Międzynarodowym Standardzie Rachunkowości 41 (MSR) z powodu braku krajowego standardu rachunkowości w zakresie rolnictwa. Krajowy Komitet Standardów Rachunkowości podjął jednak prace nad opracowaniem Krajowego Standardu Rachunkowości (KSR) poświęconego rolnictwu. Opublikowany KSR nr 12 Działalność rolnicza ma zastosowanie po raz pierwszy do sprawozdań finansowych sporządzonych za rok obrotowy rozpoczynający się od 1 stycznia 2018 roku ${ }^{28}$.

\subsection{Definiowanie podstawowych pojęć dotyczących rolnictwa - MSR 41 Rolnictwo i KSR 12 Działalność rolnicza}

Międzynarodowy Standard Rachunkowości 41 (MSR) określa sposób księgowania, prezentację w sprawozdaniach finansowych oraz ujawnianie informacji na temat działalności rolniczej. Jego celem jest zapewnienie, aby sprawozdania finansowe ujawniały niezbędne informacje na temat działalności rolniczej i aktywów biologicznych. W MSR 41 nastąpiło zdefiniowanie wielu pojęć mających znaczenie dla praktyki gospodarczej. Według standardu działalność rolnicza oznacza „zarządzanie przez jednostkę

${ }^{27}$ Harmonizacja zasad rachunkowości w postaci MSSF/MSR zapewnia porównywalność, zrozumiałość i przydatność informacji finansowych komunikowanych w sprawozdaniach finansowych. Ułatwia to współpracę różnych podmiotów na globalną skalę.

${ }^{28}$ Krajowy Standard Rachunkowości nr 12 Działalność rolnicza, Dz.U. MF z 2018 r., poz. 78. 
przemianą biologiczną i zbiorem/pozyskaniem przeznaczonych na sprzedaż lub zamianę aktywów biologicznych - w produkty rolne lub w inne aktywa biologiczne"29. Za przykład działalności rolniczej może posłużyć hodowla zwierząt, uprawa roślin jednorocznych czy wieloletnich, uprawa roślin ozdobnych. Z kolei składnik aktywów biologicznych to zwierzę znajdujące się w hodowli lub w chowie i roślina uprawna. Zbiorowość podobnych zwierząt hodowlanych lub roślin uprawnych tworzy grupę aktywów biologicznych. Dopuszcza się możliwość grupowania w zbiory w sposób uzasadniony i logiczny, np. według wieku.

Produkty rolne to produkty zebrane/pozyskane z aktywów biologicznych należących do jednostki. Zbiory/pozyskanie to moment, w którym następuje oddzielenie produktu od aktywów biologicznych lub moment zakończenia procesów życiowych aktywów biologicznych. Jednocześnie MSR 41 podaje przykłady aktywów biologicznych (np. drzewa leśne, krzewy, drzewa owocowe, bydło mleczne, trzoda chlewna), produktów rolnych będących wynikiem przetwarzania po zbiorach/pozyskaniu (odpowiednio: drzewa ścięte, liście, zebrane owoce, mleko, tusza) oraz produktów jako wynik procesu przetwarzania aktywów po zbiorach/pozyskaniu (odpowiednio: tarcica, kłody drzewne; herbata, suszony tytoń; przetworzone owoce, ser, wędliny). Zarówno oddzielona od aktywu biologicznego część, jak i samo aktywo biologiczne, które zaprzestało procesów życiowych, jest produktem rolnym. Uwzględniając kryterium przeznaczenia składnika, aktywa biologiczne dzieli się na ${ }^{30}$ :

1. Aktywa konsumpcyjne: składniki, które pozyskuje się jako produkty rolnicze bądź sprzedaje je jako aktywa biologiczne, np. inwentarz przeznaczony na produkcję mięsa, a także na sprzedaż; uprawy zbóż, roślin warzywnych, produkty rolnicze (np. wełna, mleko).

${ }^{29}$ Międzynarodowy Standard..., s. 1253.

${ }^{30}$ D. Czerwińska-Kayzer, A. Bieniasz, dz. cyt., s. 47. Zdaniem autorek podział aktywów związanych z działalnością rolniczą według przeznaczenia czy stopnia dojrzałości nie jest jednoznaczny, co utrudnia ich właściwe zaszeregowanie w sprawozdaniu finansowym. 
2. Aktywa produkcyjne: składniki wykorzystywane do wytworzenia innych aktywów biologicznych (do reprodukcji) oraz produktów rolniczych (do produkcji), np. inwentarz żywy utrzymywany w celu pozyskiwania mleka (krowy mleczne), drzewa owocowe, krzewy roślin jagodowych, winorośla.

W ramach tych aktywów wyróżnia się aktywa dojrzałe, które osiągnęły fazę gotowości do zbioru lub stan umożliwiający regularne zbiory (np. drzewa owocowe), oraz niedojrzałe, które wymienionych cech nie osiągnęły.

Działalność rolnicza polega na zarządzaniu procesem biologicznej transformacji zachodzącej w aktywach biologicznych, a prowadzącej do ich sprzedaży, przeobrażenia w produkty rolne bądź wytworzenia dodatkowych aktywów biologicznych. Obejmuje ona różnorodne czynności (np. hodowla i chów inwentarza żywego, leśnictwo, uprawy roślin wieloletnich, jednorocznych, ogrodnictwo, hodowla ryb), które jednak posiadają pewne cechy wspólne, takie jak: zdolność do biologicznej przemiany, zarządzanie zmianą i pomiar zmiany. Przemiana biologiczna powoduje:

1. Procesy wzrostu (np. powiększenie lub naprawa jakościowa zwierząt znajdujących się w hodowli i w chowie lub roślin uprawnych), umniejszenia (degeneracji, powodującej zmniejszenie ilości lub pogorszenie jakości zwierząt lub roślin) lub rozmnażania (pozyskiwania dodatkowych sztuk zwierząt lub roślin).

2. Wytworzenie produktów rolnych (np. wełny, mleka, liści herbaty).

Wynikające z przemiany biologicznej zmiany jakościowe (np. zawartość białka, poziom tłuszczu) i zmiany ilościowe (np. ilość potomstwa, długość i średnica włókien) są mierzone i monitorowane w ramach rutynowego zarządzania. Umiejętne zarządzanie zmianą pomaga w biologicznej przemianie przez zwiększanie lub przynajmniej stabilizowanie warunków niezbędnych do zaistnienia procesu (np. wilgotność, dostęp do światła). Tak zdefiniowane zarządzanie ułatwia odróżnienie działalności rolniczej od innych rodzajów działalności. Zbiory/pozyskanie ze źródeł 
niepodlegających zarządzaniu, nie są zaliczane do działalności rolniczej (np. połowy oceaniczne lub wycinka lasów).

Ujawnienia informacji związanych z prowadzoną działalnością rolniczą dotyczą m.in. kwoty zysku lub straty za bieżący okres powstałej w momencie początkowego ujęcia aktywów biologicznych i produktów rolnych, łączną kwotę zysku lub straty z tytułu zmian wartości aktywów biologicznych, opis grup aktywów biologicznych oraz metodę przyjętą w celu ustalenia wartości godziwej wszystkich grup produktów rolnych w momencie zbiorów lub pozyskania grup aktywów biologicznych.

Reasumując, w myśl MSR 41 działalność rolnicza opiera się na składnikach, określonych mianem aktywów biologicznych. Są one kontrolowane przez człowieka i stwarzają warunki przyrodnicze do przebiegu procesów, które są przetwarzane w inne aktywa biologiczne lub produkty rolnicze. Proces przemiany kończy się w momencie zbioru lub pozyskania produktu rolniczego. Zakres tematyczny KSR nr 12 przedstawia tabela 7.1.

Tabela 7.1. Zakres tematyczny KSR nr 12 Działalność rolnicza

Zakres KSR nr 12

Charakterystyka

Wyjaśnienie głównych zasad (polityki) rachunkowo-

Cel standardu ści stosowanych do działalności rolniczej zgodnie z UoR. Przedmiot: aktywa biologiczne i niebiologiczne produkty rolnicze, przychody, koszty i wyniki finansowe

Podstawowe definicje i klasyfikacje

Aktywa biologiczne, podział ich na trwałe i obrotowe, działalność rolnicza, przemiana biologiczna, zbiór lub pozyskanie, produkty rolnicze

Konieczność określenia zasad wyceny i ujmowania

Zasady rachunkowości

rolniczej i techniczno-organizacyjne sposoby prowadzenia ksiąg rachunkowych biologicznych aktywów trwałych i obrotowych, niebiologicznych produktów rolniczych oraz ustalania wyniku finansowego wraz z uwzględnieniem specyfiki prowadzonej działalności (np. złożoność i różnorodność prowadzonej działalności, rozbieżności między czasem ponoszenia nakładów i czasem osiągania efektów) 
Wycena na moment początkowego ujęcia i na każdy dzień bilansowy z podziałem na aktywa trwałe i obrotowe. Podstawa wyceny to cena nabycia, koszt wytworzenia, cena sprzedaży (biologiczne aktywa trwałe

Wycena i ujęcie w księgach rachunkowych biologicznych aktywów trwałych i obrotowych i obrotowe na moment wyceny początkowej). Wycena na dzień bilansowy:

a) biologiczne aktywa trwałe: według wartości początkowej powiększonej o koszty ulepszeń, pomniejszonej o odpisy amortyzacyjne i odpisy z tytułu utraty wartości.

b) biologiczne aktywa obrotowe: w koszcie wytworzenia nie wyższym od ceny sprzedaży netto

Sposób przeprowadzenia kalkulacji kosztu wytworzenia produktów rolniczych z wykorzystaniem przekroUstalanie przychodów i kosztów wytworzenia sprzedanych produktów rolniczych jów ewidencyjnych poniesionych kosztów (klasyfikacja i kalkulacja kosztów według kosztów produkcji zwierzęcej i roślinnej, grupowanie kosztów w układzie rodzajowym lub funkcjonalnym (koszty bezpośrednie i pośrednie), etapy kalkulacji kosztu wytworzenia produktu rolniczego. Przychody ze sprzedaży z podziatem na produkty zwierzęce i roślinne

Wsparcie działalności rolniczej

Uwzględnienie następujących form wsparcia: dotacje, płatności bezpośrednie, zwroty oraz pomoc.

Prezentacja i ujawnianie informacji

Przykłady i schematy. Wykaz kont księgowych wykorzystanych w standardzie
Aktywa trwałe i aktywa obrotowe, przychody ze sprzedaży z podziałem na produkcję zwierzęcą i roślinną, informacje dodatkowe i objaśnienia

Kalkulacja kosztów, wycena i ewidencja produktów, ewidencja ilościowa, ewidencja wartościowa, ustalenie wartości początkowej, ustalanie faz produkcji rolniczej, kwoty wsparcia i ewidencja wsparcia, prezentacja elementów sprawozdania finansowego

Źródło: opracowanie własne na podstawie: KSR nr 12 Działalność rolnicza, Dz. U. MF z 2018 r., poz. 78. 
Wyjaśnienia zawarte w KSR 12 są zgodne w podstawowym zakresie z postanowieniami MSR 41 Rolnictwo. Przewidziana w MSR 41 wycena aktywów biologicznych w wartości godziwej wydaje się najistotniejszą kwestią różniącą ujęcie takich aktywów w świetle KSR 12. Wykorzystanie wartości godziwej do wyceny powoduje, że wynik finansowy obliczany jest na moment pozyskania produktów rolniczych, a nie ich sprzedaży.

\subsection{Wycena aktywów biologicznych i produktów rolnych}

Ujmowanie to proces uwzględniania $\mathrm{w}$ bilansie lub w sprawozdaniu z dochodów pozycji spełniających definicje danego składnika i kryteria jego ujmowania. Ogólne kryteria ujmowania składnika aktywów, w tym także aktywów biologicznych to:

1. Jednostka kontroluje składnik aktywów w wyniku przeszłych zdarzeń (jednostka posiada prawny tytuł własności).

2. Istnieje prawdopodobieństwo, że jednostka uzyska przyszłe korzyści ekonomiczne związane $\mathrm{z}$ tą pozycją.

3. Wartość godziwą lub cenę nabycia/koszt można wiarygodnie ustalić.

Międzynarodowy Standard Rachunkowości 41 wprowadza wymóg wyceny aktywów biologicznych w momencie pierwszej identyfikacji aktywu (w momencie początkowego ujęcia), a także wyceny na koniec każdego okresu sprawozdawczego w wartości godziwej pomniejszonej o szacowane koszty związane ze sprzedażą, chyba, że w momencie początkowego ujęcia wartości tej nie można ustalić w wiarygodny sposób (zob. tabela 7.2.).

W modelu tym odejmowane są koszty sprzedaży, co zapewnia właściwy szacunek rynkowych przyszłych korzyści ekonomicznych związanych z danym składnikiem aktywów. Międzynarodowy Standard Rachunkowości nie zajmuje się przetwarzaniem produktów rolnych po zbiorach/pozyskaniu, czyli np. przetwarzaniem owoców w wino. Tego typu przetwarzanie nie odpowiada definicji działalności rolniczej zawartej w standardzie. Podobne zasady dotyczą wyceny początkowej produktów rolnych. 
Tabela 7.2. Wycena aktywów biologicznych według MSR 41 Rolnictwo

Kategoria wyceny Warunki

Wartość godziwa pomniejszona o koszty sprzedaży (wartość godziwa: kwota za którą składnik mógłby zostać wymieniony, a zobowiązania uregulowane w transakcji przeprowadzonej na warunkach rynkowych pomiędzy niezależnymi, zainteresowanymi i dobrze poinformowanymi stronami; koszty transakcji sprzedaży to takie jak np. opłaty pośredników sprzedaży, koszty opinii, opłaty celne i inne podatki)

Aktualne ceny transakcji rynkowych (ceny rynkowe na podobne dobra, po korekcie wynikającej z różnic między aktywami).

Ceny branżowe

Teraźniejsza wartość netto spodziewanych przepływów pieniężnych z tych aktywów
Istnienie aktywnego rynku (należy uwzględnić rynek główny, do którego dostęp ma jednostka dokonująca wyceny, a nie rynku najkorzystniejszego dla danej jednostki, rynek, na którym jednostka w normalnych warunkach zawarłaby transakcję sprzedaży
Nie istnieje aktywny rynek, który wyznaczyłby cenę na dane aktywa biologiczne

\begin{abstract}
Brak dostępu do cen (wartości) rynkowych aktywów biologicznych. Nie uwzględnia się np. przepływów pieniężnych przeznaczonych np. na odnowienie aktywu biologicznego, np. ponowne zasadzenie drzewek
\end{abstract}

Źródło: opracowanie własne na podstawie: MSR 41 Rolnictwo, Międzynarodowe Standardy Sprawozdawczości Finansowej, SKwP, IFRS, Warszawa, Londyn, 2013, s. 1256-1257.

Wycena w wartości godziwej ma bezpośredni związek ze zmianami oczekiwań co do przyszłych korzyści ekonomicznych jednostki. Zdaniem Tomasza Kondraszuka „MSR 41 Rolnictwo jest przykładem realizacji tej właśnie nowoczesnej koncepcji definiowania i pomiaru dokonań działalności gospodarczej”31. Określenie „mógłby zostać” oznacza, że chodzi o transakcję hipotetyczną (zakłada się, że istnieje możliwość sprzedaży produkcji

${ }^{31}$ T. Kondraszuk, Projekt Krajowego Standardu Rachunkowości..., s. 219. 
w momencie jej pozyskania). Zwrot „transakcje rynkowe” wprowadza warunek niezależności stron, z kolei sformułowanie „dobrze poinformowanymi" oznacza, że kierownictwo jednostki dysponuje wystarczającą wiedzą o przedmiocie transakcji i czynnikach mających wpływ na określenie ceny i warunkach rynkowych na dzień wyceny. Podejście rynkowe w ustalaniu wartości godziwej reprezentują także inne metody wyceny oparte na cenach rynkowych, np. oparte na cenie z ostatniej przeprowadzonej transakcji czy też na podstawie transakcji dotyczących podobnych pozy$\mathrm{cji}^{32}$. Wymienione metody obarczone są z samego założenia pewną dozą subiektywizmu. Można postawić pytanie, czy bieżąca wartość rynkowa jest dobrym odzwierciedleniem wartości w rolnictwie? Wycena wartości godziwej umożliwia ujęcie i wycenę wzrostu biologicznego na podstawie informacji z aktywnych rynków czy cen ostatnich transakcji, uwzględniając datę ich dokonywania. Miedzynarodowy Standard Rachunkowości wymaga, aby zmiana wartości godziwej została ujęta w wyniku finansowym za okres, w którym miała miejsce. W takiej sytuacji jest możliwe wykazywanie dochodów przez cały okres, np. w jednostce posiadającej szkółkę leśną - od czasu zasadzenia drzew do ich wyrębu. Zwolennicy takiego stanowiska twierdzą, że przemiana biologiczna ma podstawowe znaczenie dla zrozumienia wyniku finansowego jednostki i jest zgodna $\mathrm{z}$ zasadą memoriału.

Zgodnie z modelem rachunkowości odwołującym się do wyceny w koszcie historycznym, jednostka nie może wykazywać dochodów do momentu pierwszego wyrębu i sprzedaży, co najczęściej następuje po wielu latach od zasadzenia drzew. W dynamicznym otoczeniu historyczna cena nabycia traci szybko aktualność. Inne argumenty zwolenników wartości godziwej to istnienie aktywnych rynków i możliwość ustalenia aktualnych wartości rynkowych, ponadto stosowanie cen rynkowych zdecydowanie poprawia porównywalność oraz zrozumiałość wyceny i prezentacji podobnych aktywów, które mogą mieć różne ceny nabycia lub koszty wytworzenia.

${ }^{32}$ E. Engelgardt, Możliwości zastosowania wartości godziwej w praktyce, „Zeszyty Teoretyczne Rachunkowości” 2009, t. 51(107), s. 18-19. 
Zalety te przekładają się na korzyści, jakie mogą uzyskać interesariusze sprawozdań ogólnego przeznaczenia na temat tworzenia wartości w gospodarstwie rolnym. Należy podkreślić, że w momencie początkowego ujęcia aktywów biologicznych, w przypadku braku funkcjonującego rynku, standard wprowadza wycenę w cenie nabycia lub koszcie wytworzenia. Gdy tylko to będzie możliwe, składnik aktywów powinien być wyceniony w wartości godziwej. Z kolei przeciwnicy wyceny w wartości godziwej, wśród zasadniczych problemów wymieniają częste zmiany cen rynkowych, powszechność stosowania kosztu historycznego, jako metody wyceny dominującej w zapisach innych MSSF/MSR, bardziej obiektywnej i spójnej, czy też ceny rynkowe na dzień bilansowy mogą nie mieć rzeczywistego związku z cenami, po których aktywa zostaną sprzedane, a wiele spośród aktywów biologicznych nie jest przeznaczonych na sprzedaż ${ }^{33}$.

Według KSR 12 nie można wyceniać produktów rolniczych podczas zbiorów lub pozyskania, ale ich wartość wymaga określenia nie później niż moment sprzedaży oraz na dzień bilansowy. Biologiczne aktywa trwałe są zaliczane do środków trwałych, a obrotowe do zapasów. Wycena biologicznych aktywów obrotowych następuje w momencie początkowego ujęcia w cenie nabycia, koszcie wytworzenia lub cenie sprzedaży takiego samego lub podobnego składnika, na dzień bilansowy w wartości początkowej nie wyższej od ceny sprzedaży netto lub inaczej ustalonej wartości godziwej. Biologiczne aktywa trwałe wycenia się:

- w produkcji zwierzęcej w koszcie wytworzenia,

- w produkcji roślinnej po początkowym ujęciu w cenie nabycia lub koszcie wytworzenia i pomniejsza o odpis amortyzacyjny oraz z tytułu trwałej utraty wartości.

Według KSR 12 poniesione koszty będą aktywowane w ramach zamknięcia rocznego, a nieszacowane przychody pomniejszone o koszty sprzedaży.

${ }^{33}$ Międzynarodowe Standardy Sprawozdawczości Finansowej, Część B, SKwP, IFRS, Warszawa-Londyn 2011, s. B1656. 


\section{Podsumowanie}

Reasumując zaprezentowane rozważania można stwierdzić, że:

1. Rachunkowość jest uniwersalnym systemem informacyjnym, jednak specyfika produkcji rolnej powoduje, że rachunkowość w przedsiębiorstwach rolniczych różni się od rachunkowości w przedsiębiorstwach innych działów gospodarki.

2. Przez wiele lat obowiązywania UoR, wobec braku w niej wiążących wytycznych dotyczących sposobów ujmowania działalności rolniczej, a także braku opracowania krajowego standardu w tym zakresie, MSR 12 mógł mieć zastosowanie w większych przedsiębiorstwach rolnych o charakterze towarowym do sporządzania sprawozdań finansowych lub przedsiębiorstwa przyjmowały własne rozwiązania. Powstanie MSR 41 i KSR 12 jest niewątpliwie ważnym osiągnięciem w dziedzinie rachunkowości. Zarówno MSR 41, jak i KSR 12 określają rozwiązania, które uwzględniają specyfikę działalności rolnej.

3. Obecnie przyjęte rozwiązania krajowe, pochodzące z UoR i kompleksowego opracowania KSR 12 ułatwiają ewidencję i sporządzanie rocznego sprawozdania finansowego przez krajowe gospodarstwa rolne, co powinno także ułatwić ocenę przebiegu i efektywności ekonomicznej procesu produkcji rolnej.

4. Wyjaśnienia zawarte w KSR 12 są zgodne w podstawowym zakresie z postanowieniami MSR 41 Rolnictwo. Przewidziana w MSR 41 wycena aktywów biologicznych w wartości godziwej wydaje się najistotniejszą kwestią różniącą ujęcie takich aktywów w świetle KSR 12. Niewątpliwie stosowanie tej kategorii w praktyce przedsiębiorstw rolniczych stałoby się łatwiejsze, gdyby KSR był bardziej spójny z MSR w tym zakresie.

Specyfika działalności rolniczej i złożoność problematyki jest jednocześnie szansą na rozwijanie badań w tym zakresie i wskazywanie na perspektywy badawcze $\mathrm{w}$ tym temacie. Jedną z perspektyw badawczych powinna być problematyka poświęcona zagadnieniom wykorzystywania 
danych księgowych na potrzeby zarządzania w gospodarstwach rolnych oraz realizacja idei zrównoważonego rozwoju. Z punktu widzenia gospodarstwa rolnego należy podkreślić konieczność posiadania informacji dla celów zarządzania przedsiębiorstwem rolnym na temat bieżącej kondycji finansowej. Warunkiem jest posiadanie takich informacji, a to zapewnia właściwie prowadzona rachunkowość jednostki. 